\title{
HWWI
}

\section{Cultural Diversity and Economic Performance: Evidence from European Regions}

Elena Bellini, Gianmarco I.P. Ottaviano, Dino Pinelli, Giovanni Prarolo

\section{HWWI Research}

Paper 3-14

by the

HWWI Research Programme

Migration Research Group 
Corresponding author:

Giovanni Prarolo

Università di Bologna and Fondazione Eni Enrico Mattei, Mailand giovanni.prarolo@unibo.it

HWWI Research Paper

Hamburg Institute of International Economics (HWWI)

Heimhuder Str. 71 | 20148 Hamburg | Germany

Phone +49 (0)40 340576 - 0 | Fax +49 (0)40 340576 - 776

info@hwwi.org|www.hwwi.org

ISSN 1861-504X

Editorial Board:

Thomas Straubhaar (Chair)

Tanja El-Cherkeh

() Hamburg Institute of International Economics (HWWI)

April 2008

All rights reserved. No part of this publication may be reproduced, stored in a retrieval system, or transmitted in any form or by any means (electronic, mechanical, photocopying, recording or otherwise) without the prior written permission of the publisher. 


\title{
CULTURAL DIVERSITY AND ECONOMIC PERFORMANCE: EVIDENCE FROM EUROPEAN REGIONS ${ }^{1}$
}

\author{
Elena Bellini (FEEM) \\ Gianmarco I.P. Ottaviano (Università di Bologna, FEEM and CEPR) \\ Dino Pinelli (European Commission) \\ Giovanni Prarolo (Università di Bologna and FEEM)
}

\begin{abstract}
We investigate the relationship between diversity and productivity in Europe using an original dataset covering the NUT3 regions of 12 countries of the EU15 (Austria, Belgium, Denmark, France, former Western Germany, Ireland, Italy, the Netherlands, Portugal, Spain, Sweden and the United Kingdom). In so doing, we follow the empirical methodology developed by Ottaviano and Peri (2006a) in the case of US cities. The main idea is that, as cultural diversity may affect both production and consumption through positive or negative externalities, the joint estimation of price and income equations is needed to identify the dominant effect. Based on this methodology, we find that diversity is positively correlated with productivity. Moreover, we find evidence that causation runs from the former to the latter. These results for EU regions are broadly consistent with those found by Ottaviano and Peri for US cities.
\end{abstract}

\footnotetext{
${ }^{1}$ Corresponding author: Giovanni Prarolo, Università di Bologna and FEEM, giovanni.prarolo@unibo.it. We thank Andrea Ichino, Francesco Damuri and Giovanni Peri as well as seminar participants at FEEM and the University of Bologna for comments. We thank the European Commission and the Volkswagen Foundation for financial support.
} 


\section{Introduction}

Cultural diversity has become a central issue for policy-making in the EU. This is the result of growing international flows in goods, factors and knowledge that are fostering the global interactions among a rising and increasingly diversified number of people. At the EU, this global phenomenon is reinforced by the twin processes of deeper integration and enlargement.

The current debate on the issue is 'double faced'. On the one hand, the official rhetoric looks at diversity as an important asset for human development and welfare. For instance, at the global level the 2001 Universal Declaration on Cultural Diversity of the United Nations Educational Scientific and Cultural Organisation (UNESCO) states that "cultural diversity is as necessary for humankind as biodiversity is for nature" (Art. 1). Similarly, at the EU level diversity is often seen as the core concept of European identity as stressed by the motto "United in Diversity" in the proposed European Constitution. On the other hand, the general public perceives immigration as very problematic. The relevance of the 'Polish plumber' in the French debate on the European Constitution and the calls for restrictions to immigration in several European countries are two revealing examples.

From an economic point of view, the key question is whether a culturally diversified society is more or less efficient than a culturally homogenous one. The answer is not obvious and equally 'double faced'. On the one hand, cultural diversity creates potential benefits by increasing the variety of goods, services and skills available for consumption, production and innovation (Lazear 1999; O'Reilly Williams and Barsade 1998; Ottaviano and Peri 2005 and 2006a; Berliant and Fujita 2004). On the other hand, cultural diversity generates potential costs as it may entail racism and prejudices resulting in open clashes and riots (Abadie and Gardeazabal 2003), as well as conflicts of preferences leading to a suboptimal provisions of public goods (Alesina, Baqir and Easterly 1999; Alesina, Baqir and Hoxby 2004). 
Recent evidence on US data show that richer diversity is indeed associated with higher wages and productivity of natives with causation running from the former to the latter (Ottaviano and Peri 2005; Ottaviano and Peri 2006a,b). Comparable results are found by Manacorda, Manning and Wadsworth (2007) for the UK as well as by D'Amuri, Ottaviano and Peri (2008) for Germany. A comprehensive analysis of the effects of diversity on productivity across EU countries is, nonetheless, still missing. Our aim is to take a first step in this direction. In so doing, we assemble a new dataset covering the NUT3 regions of 12 countries of the EU15 (Austria, Belgium, Denmark, France, former Western Germany, Ireland, Italy, the Netherlands, Portugal, Spain, Sweden and the United Kingdom). Then, we follow the empirical methodology developed by Ottaviano and Peri (2006a) in the case of US cities. The main idea is that, as cultural diversity may affect both production and consumption through positive or negative externalities, the joint estimation of price and income equations is needed to identify the dominant effect. Based on this methodology, we find that diversity is positively correlated with productivity. Moreover, through instrumental variable estimation, we find evidence that causation runs from the former to the latter. These results for EU regions are broadly consistent with those found by Ottaviano and Peri (2005 a,b) for US cities.

The rest of the paper is organised as follows. Section 2 summarises the economic literature on diversity and places our contribution into context. Section 3 describes the dataset. Section 4 discusses the measures of diversity. Section 5 presents some stylised facts about the diversity of EU regions. Section 6 introduces the theoretical model. Section 7 discusses the results of the econometric analysis. Section 8 concludes.

\section{The literature on diversity}

The link between cultural diversity and economic performance has attracted considerable attention over the last decade. Using cross-country regressions, an early paper by Easterly and Levine (1997) shows that richer diversity is associated with slower economic growth. ${ }^{2}$ Despite strong criticism (see for example Arcand et al 2000),

\footnotetext{
${ }^{2}$ Easterly and Levine (1997) use a fractionalisation index of diversity calculated from the Midas Atlas database.
} 
that result has been confirmed by a number of studies. In particular, Alesina and La Ferrara (2005) find that going from perfect homogeneity to complete heterogeneity (i.e., the index of fractionalisation going from 0 - there is just one group - to 1 - each individual belongs to a different group) would reduce a country yearly growth performance by 2 per cent. Angrist and Kugler (2003) find a small but significant negative impact of migration on employment levels in the EU. La Porta et al (1999) and Alesina et al (2003) argue that higher levels of diversity might result in suboptimal decisions on public good provisions, consequently damaging growth performance in the long-run. They show that diversity is negatively correlated with measures of infrastructure quality, illiteracy and school attainment, and positively correlated with infant mortality. Similarly, Alesina, Glaeser and Sacerdote (2001) find that richer diversity is associated with lower levels of social spending and social transfers by the government. The interpretation is that 'redistributive policies' are less valued in ethnically fragmented societies.

However, the conclusion that diversity has a negative effect on the economy need to be further qualified. Collier (2001) argues that diversity has negative effects on productivity and growth only in non-democratic regimes. Alesina and La Ferrara (2005) find that diversity has a more negative effect at lower levels of income (implying that poorer countries suffer more from ethnic fragmentation). Easterly (2001) constructs an index of institutional quality aggregating data from Knack and Keefer (1995) on contract repudiation, expropriation, rule of law and bureaucratic quality. He finds that the negative effect of ethnic diversity is significantly mitigated by 'good' institutions.

Moreover, a number of studies relating diversity to urban agglomeration suggest that diversity can have also positive economic consequences. Jacobs (1961) sees diversity as the key factor of success of a city: the variety of commercial activities, cultural opportunities, inhabitants, visitors as well as the variety of tastes, abilities, needs and even obsessions are the engine of urban development (Jacobs, 1961, p 137). Sassen (1994) studies 'global cities' - such as London, Paris, New York and Tokyo - and their strategic role in the development of activities that are central to world economic growth and innovation, such as financial and other specialised services. A key characteristic of 
'global cities' is the cultural diversity of their population. Bairoch (1985) sees cities and their diversity as the engine of economic growth. More recently, Florida (2002) argues that diversity contributes to attract knowledge workers, thereby increasing the creative capital of cities and the long-term prospect of knowledge-based growth (Gertler, Florida, Gates and Vinodrai 2002).

These insights suggest that cross-country comparisons may not target the correct level of aggregation to identify the possible positive effect of diversity. Finer spatial units, such as cities, where differences more easily interact, seem more appropriate laboratories. The focus on cities also allows one to control for differences in institutional quality and stage of development. Glaeser, Scheinkman and Shleifer (1995) examine the relationship between a variety of urban characteristics in 1960 and urban growth (income and population) between 1960 and 1990 across US cities. They find that racial composition and segregation are basically uncorrelated with urban growth. However, segregation seems to positively influence growth in cities with large nonwhite communities. Alesina and La Ferrara (2005) use the basic specification of Glaeser, Scheinkman and Shleifer (1995) to estimate population growth equations across US counties over 1970-2000. Consistently with their result at the country level discussed above, they find that diversity has a negative effect on population growth in initially poor counties and a less negative (or positive) effect for initially richer counties. Following Roback (1982), Ottaviano and Peri (2006a) develop a model of a multicultural system of open cities that allows them to use the observed variations of wages and rents of US-born workers to identify the impact of cultural diversity on productivity. They find that on average, US-born citizens are more productive in a culturally diversified environment. This is robust to the use of instrumental variables, thus implying a causal relationship from diversity to productivity. This result is qualified in two specific respects. First, local diversity has a negative effect on the provision of public goods, which is consistent with previous findings at the national level. Second, the positive effects are stronger when only second and third generation immigrants are considered, which suggests that the positive effects are reaped only when some degree of integration between communities takes place. 
The foregoing in insights somehow contrast with earlier findings by Borjas (1995 and 2003) showing a negative impact of immigrants on the wages of natives and a positive impact on capital returns. However, these findings rely on the key assumptions of perfect substitution between natives and foreigners as well as on a fixed capital stock. Allowing for imperfect substitutability between natives and foreigners as well as endogenous capital accumulation, Ottaviano and Peri (2006b) find that the effects of immigration on the average wages of natives turn positive and rather large. Moreover, they find that the effect is particularly strong for the most educated (college graduates) and negative for the least educated (high-school drop-outs). The latter result is consistent with analysis showing a negative impact of immigrants on the relative wages of less educated workers (Borjas 1994, 1999, 2003; Borjas, Freeman and Katz 1997; and to a minor extent Butcher and Card 1991; Card 1990 and 2001; Friedberg 2001; Lewis 2003).

The existing literature is based either on cross-country analyses or focuses primarily on the US. This is not only because diversity is one of the hallmarks of the US society, but also for the pragmatic reason that US data are richer and of better quality. Recent exceptions are Manarcorda, Manning and Wadsworth (2007) and D'Amuri, Ottaviano and Peri (2008) who find results similar to Ottaviano and Peri (2006b) in the case of the UK and Germany respectively. The present analysis supplements these national studies by providing an overview of the relationship between diversity and economic performance across a large set of European regions. This represents a relevant addition to the literature as insights gained from US analyses may not apply to the EU. First of all, contrary to the US, in Europe cultural differences are historically inherited and are largely enshrined in national states (with established regional minorities either recognised or challenged by the national states). The migration flows over the last two centuries (from southern to northern Europe and from the colonies to colonial powers) have not dramatically altered this situation and simply led to the establishment of relatively stable ethnic communities in some European states. This situation is now changing as an increasing flow of people is crossing the EU national borders from inside and outside of the EU thereby, which has revived the public debate. Second, as 
shown by Angrist and Kugler (2003), labor market institutions may be important in mediating the effects of immigration on wages and employment and these institutions vary a lot between the US and continental Europe.

\section{The dataset ${ }^{3}$}

Our dataset includes demographic, economic and geographical data for over 900 European regions from 12 countries of the EU15 (Austria, Belgium, Denmark, France, former Western Germany, Ireland, Italy, the Netherlands, Portugal, Spain, Sweden and the United Kingdom). Data are collected at NUTS 3 level (equivalent to county in the UK, province in Italy or arrondissement in France) and refer to two different points in time: 1991 (1990 for Finland and the Netherlands) and 2001 (2000 for Finland and the Netherlands; 1999 for France). The choice of reference years is constrained by the availability of Census data in each country (more on this below).

Economic data include GDP, employment (3-sector level), unemployment, active population as well as hotel and restaurant prices. These are used to proxy unavailable information on land prices (more on this below). GDP, employment, unemployment, and active population are from Eurostat's Cronos REGIO database. When data are not available at NUTS 3 level, they are interpolated by using NUTS 2 data (kindly provided by Cambridge Econometrics). Geographical data include the areas (in square $\mathrm{Km}^{2}$ ) of the region (from the Eurostat's REGIO database) and a travel time matrix (kindly provided by the European Commission DG Regio). Geographical data are used to calculate the density of population and the 'market potential' of each region. This measures the economic centrality of a region and is calculated as the weighted average of the GDP of that region and the GDP's of the surrounding regions, with weights inversely related to the travel time (by car).

Hotel and restaurant prices are used to proxy for local price indexes that are unavailable at NUTS 3 level. They have been chosen because typically they are highly correlated

\footnotetext{
${ }^{3}$ The dataset has been developed at Fondazione Eni Enrico Mattei with support from the European Commission, 6th RTD Framework Programme, Contract n ${ }^{\circ}$ SSP1-CT-2003-502491 (PICTURE).
} 
with the prices of non-tradables, in particular of land, which have been used by Ottaviano and Peri (2005) to disentangle the productivity and the amenity effects of diversity. Hotel and restaurant prices are derived from the Michelin Guide of each country for the reference years. By exploiting the rating system of Michelin, we have constructed price indexes that refer to restaurants and hotels of comparable quality across countries and cities. In particular, the hotel (restaurant) price for each region is calculated by averaging across the prices of all two-houses hotels (two forchettes restaurants) reported in the guide for that region. Hotel prices are for a two-bed room with no breakfast included. Restaurant prices exclude fixed-price menus.

Demographic data are constructed from the National Statistical Institutes of each country (mostly from national Census Surveys or Registry data) and cover population by gender, age $(0-14 ; 15-39 ; 40-64 ; 65$ or more), marital status (unmarried, married, divorced, widow) and level of education (basic or not educated, secondary school, degree or higher education - harmonized using the ISCED classification of the OECD) and citizenship (country of birth for the UK and Ireland) grouped by main area of provenience to achieve a common classification (autochthonous, other UE countries, other European countries, Africa, America, Asia, Oceania, unknown).

\section{Measuring diversity}

'Cultural diversity' is the central variable of our analysis. As such, it has to be carefully measured. In particular, its measurement requires two steps. ${ }^{4}$ First, it is necessary to find one or more criteria to distinguish 'cultural groups' within the population. In ethnology the 'right list' of groups (Fearon 2003) would be based on a process of 'selfcategorisation' where people recognize the distinction of groups and anticipate that significant actions are or could be conditioned on belonging or not to a group. A direct approach to the identification would involve carrying out worldwide surveys. Because of the costs involved, no such experiment has been carried out and indirect approaches 
have been used in literature. Indirect approaches require the choice of one or more 'identity markers' as a basis for the identification of the groups. Extra and Yağmur (2004) compare the theoretical strengths and weaknesses of four possible 'identity markers' (nationality, country of birth, language spoken at home and selfcategorisation). Table 1 summarises their results.

\footnotetext{
4 Whittaker (1972) distinguishes $\alpha$-diversity (the diversity of a given population, or inventory diversity), and $\beta$-diversity (the variation of diversity across different populations, or differentiation diversity). Here, we will only use $\alpha$-diversity measures, as we only refer to diversity within regions.
} 
Table 1: Criteria for the definition and identification of population groups in a multicultural society (P/F/M = person/father/mother)

\begin{tabular}{|c|c|c|}
\hline Criterion & Advantages & Disadvantages \\
\hline $\begin{array}{l}\text { Citizenship } \\
\text { (CIT) }\end{array}$ & $\begin{array}{ll}\text { - } & \text { objective } \\
\text { - } & \text { relatively easy to establish }\end{array}$ & $\begin{array}{l}\text { - (intergenerational) erosion through } \\
\text { naturalisation or double CIT } \\
\text { - CIT not always indicative of } \\
\text { ethnicity/identity } \\
\text { - some (e.g., ex-colonial) groups have } \\
\text { CIT of immigration country }\end{array}$ \\
\hline $\begin{array}{l}\text { Country-of-birth } \\
(\mathrm{CoB})\end{array}$ & $\begin{array}{ll}\text { - } & \text { objective } \\
\text { - } & \text { relatively easy to establish }\end{array}$ & $\begin{array}{l}\text { - intergenerational erosion through } \\
\text { births in immigration country } \\
\text { - CoB not always indicative of } \\
\text { ethnicity/identity } \\
\text { - invariable/deterministic: does not } \\
\text { take account of dynamics in society } \\
\text { (in contrast of all other criteria) }\end{array}$ \\
\hline $\begin{array}{l}\text { Self-categorisation } \\
\text { (SC) }\end{array}$ & $\begin{array}{l}\text { - touches the heart of the matter } \\
\text { - emancipatory: SC takes account of } \\
\text { person's own conception of } \\
\text { ethnicity/identity }\end{array}$ & 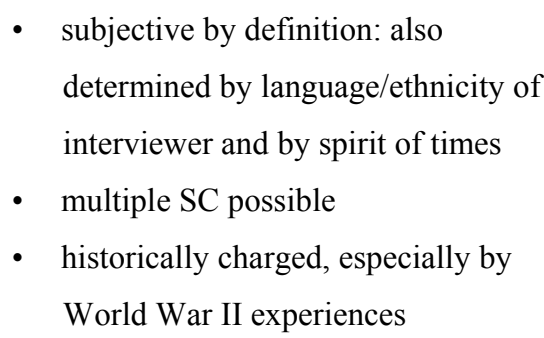 \\
\hline $\begin{array}{l}\text { Home language } \\
\text { (HL) }\end{array}$ & $\begin{array}{l}\text { - HL is the most significant criterion of } \\
\text { ethnicity in communication processes } \\
\text { - HL data are prerequisite for } \\
\text { government policy in areas such as } \\
\text { public information or education }\end{array}$ & $\begin{array}{l}\text { - complex criterion: who speaks what } \\
\text { language to whom and when? } \\
\text { - language is not always core value of } \\
\text { ethnicity/identity } \\
\text { - useless in one-person households }\end{array}$ \\
\hline
\end{tabular}

(source: Extra and Yağmur 2004:31)

At national level, the best known and most widely used effort to distinguish 'cultural groups' within countries was carried out by a team of Soviet ethnographers in the early 1960s and published as Atlas Narodov Mira. The Soviet team mainly used language to define groups, but sometimes included groups that seem to be distinguished by some notion of race rather than language, and quite often used national origin (Fearon 2003). 
In the attempt of clearing from potential sources of arbitrariness (why should one use language alone in one case, language and race in a second one and language and national origin in a third one?) Alesina et al (2003) develop separate measures based on linguistic and religious groups (as well as ethnic groups, as a combination of the two) in a sample of about 190 countries.

At regional and urban level, data are much more scattered. For European regions, the only identity marker available is 'citizenship' ('country of birth' for the UK and Ireland), which is subject to intergenerational erosion. For the US, Ottaviano and Peri (2005, 2006a) compare measures of urban diversity based on country-of-birth, language-spoken-at-home, citizenship and race. They find that such measures are highly correlated across cities. This is true to a lesser extent also for religion. The bias introduced by the citizenship-based measure of diversity may therefore not be too large. In Europe, however, the problem of intergenerational erosion is reinforced by the fact that Member States have different citizenship laws and therefore different naturalisation rates. We will discuss in Section 7 the implications for the econometric analysis and how we deal with them.

The second step towards diversity measurement involves the construction of a synthetic index. A plethora of indexes have been proposed from biology to economics. Here we adopt two of the most used indexes in the relevant economic literature. The first is simply the share of foreigners in the whole resident population. The second is the fractionalisation index. Given a population of $L_{c}$ individuals divided in $i=1 \ldots M$ cultural groups, the fractionalisation index can be calculated as:.

(1) $d_{c}=1-\sum_{i=1}^{i=M}\left(\frac{L_{c i}}{L_{c}}\right)^{2}$

where $L_{c i}$ is the number of individuals that in city $c$ belong to group $i$. The index is widely used in biology, where it is known as the Simpson index of diversity. It corresponds to the complement to one of the Herfindal index of concentration across groups. It measures the probability that two individuals randomly extracted from the 
population belong to different groups. The index varies between 0 and 1 and increases with both the number of groups and the evenness of the distribution of individuals across groups.

\section{Diversity in European regions}

We can now use the database presented in Section 3 and the indexes of diversity introduced In Section 4 to discuss the main features of the European landscape of diversity and how this has changed over the period 1991 to 2001.

Figure 1 shows the percentage of foreigners in European regions in $1991 .^{5}$ At that time, diversity characterised only regions in the core of Europe: France around Paris and Lyon, Belgium, the Netherlands, Germany's large cities and the south of the UK. Regions of Spain, Italy, Austria and Nordic countries were fairly homogenous. In Italy and Spain the percentage of residents with foreign citizenship was below 2\% everywhere. The situation has rapidly changed over the 1990s. In 2001 (see Figure 2) most of Austrian regions have reached a percentage of foreigners higher than $8 \%$ and the percentage of foreigners in most regions of Italy and Spain is between 4 and $8 \%$. Overall, the share of foreigners increased from $5.6 \%$ in 1991 to $6.9 \%$ in 2001 .

The data also allow for some analysis in terms of migrants' provenience. Among the regions of which we have data, the largest group of foreign population is represented by migrants from other EU15 countries (representing around 1.9\% of population in 1991), but this group has not significantly increased over the decade. Migrants from Africa represent the second largest group (1.4\% of population in 2001) followed by Asian and other European (1\% and $1.3 \%$ of population in 2001, respectively). Contrary to migrants from the EU, the number of migrants from those three groups has been growing very fast with an increase of over a third during the decade.

Figure 3 and Figure 4 show the percentage of foreigners respectively from inside and outside the EU15. Figure 3 shows a geographical pattern that is very similar to the one

\footnotetext{
${ }^{5}$ Here and in what follows, we will refer to 'foreigner' as 'foreign-born' in the UK and Ireland, and 'with foreign citizenship' elsewhere.
} 
shown in Figure 1 with the highest shares in the core regions of Europe and very little outside. Hence, internal migration flows tend to reproduce old core-periphery patterns. Figure 4 is more similar to Figure 2 with relatively high shares also in the regions of Austria, Italy and Spain. Contrary to migrants from the EU, recent migration flows from outside seem to affect to a greater extent the regions of more recent immigration, particularly those that are close to the Mediterranean (Italy and Spain) and the Eastern border (former East Germany, Austria and Sweden).

Figure 1. Shares of foreigners in European regions, 1991

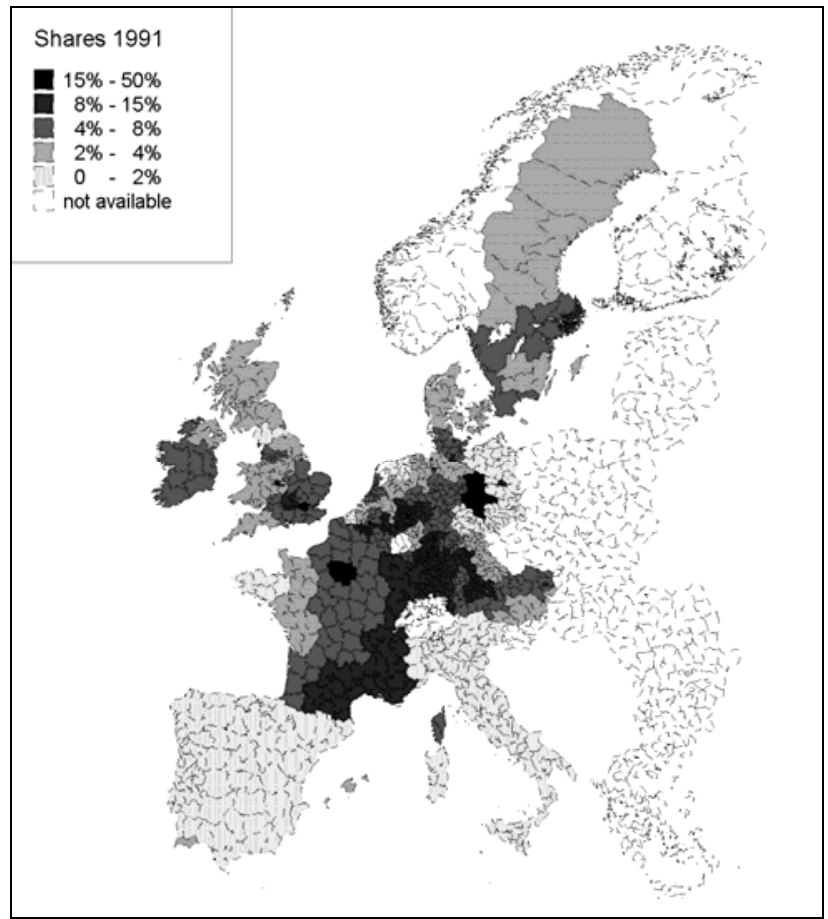


Figure 2. Shares of foreigners in European regions, 2001

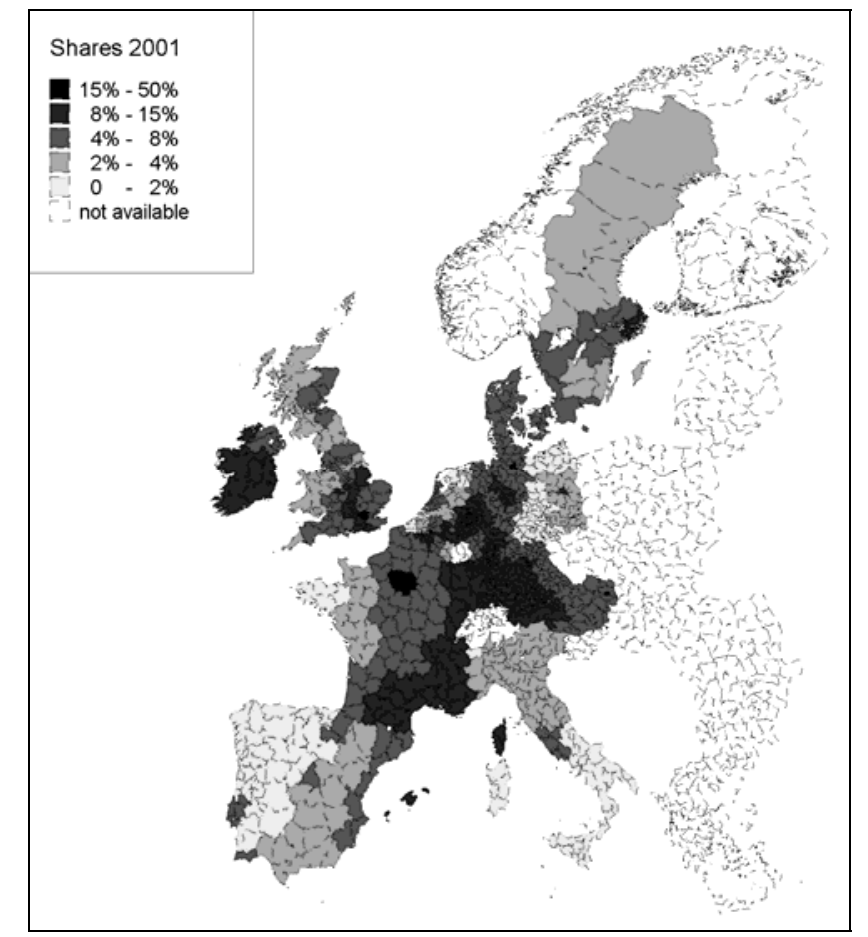

Figure 3: Share of foreigners from within the EU15, 2001

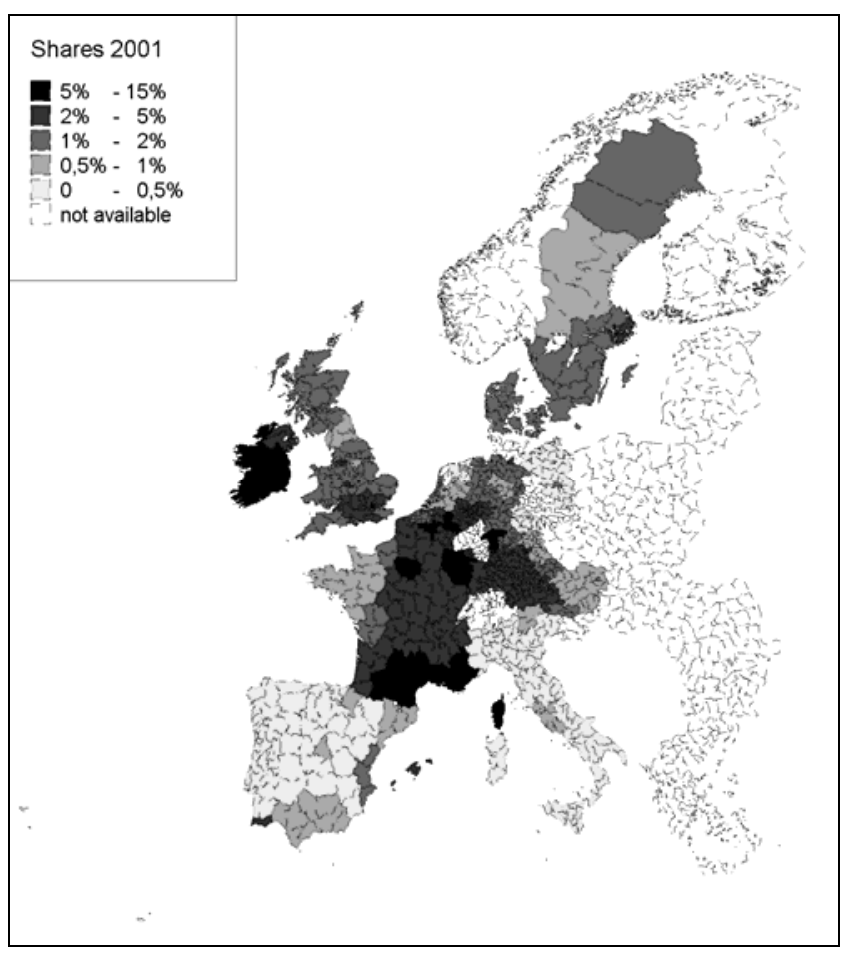


Figure 4: Share of foreigners from outside the EU15, 2001

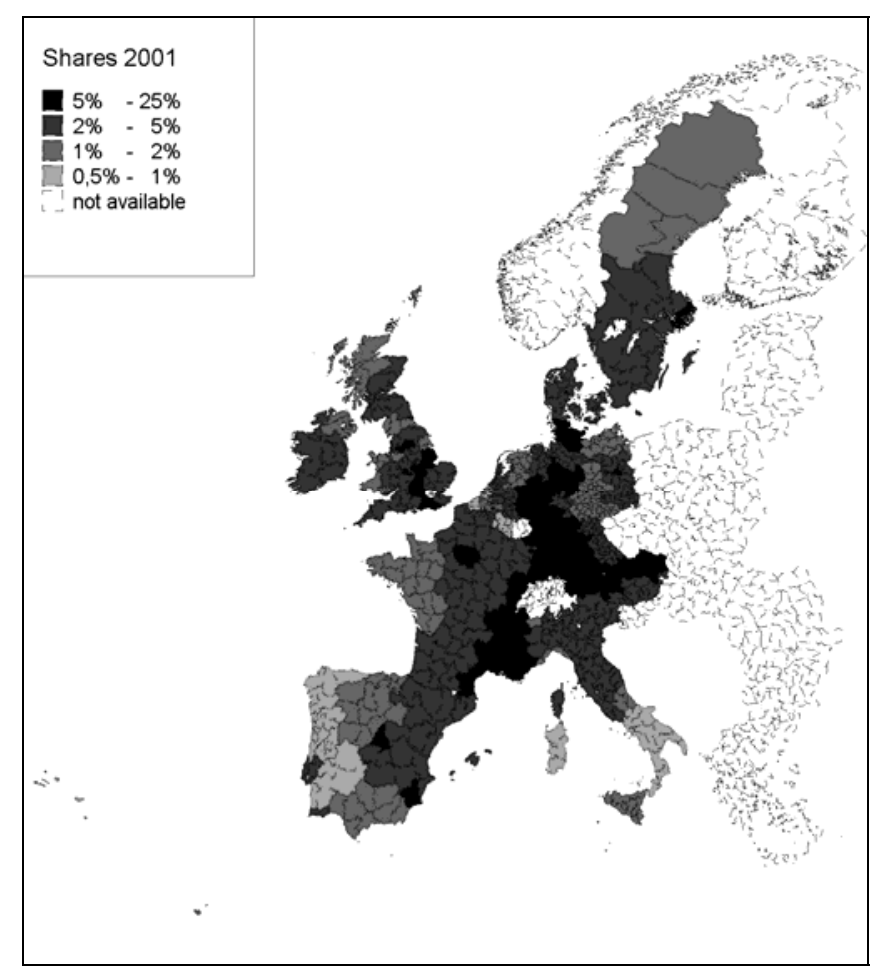

Table 2 shows the most and the least diverse EU regions in 1991 and 2001 ranked according to the Simpson index of diversity (fractionalization) discussed in Section 4. The share of foreigners in total population is also reported. Urban regions are at the top of the ranking both in 1991 and 2001. French and UK regions reach the highest score in both cases, joined in 2001 by Bruxelles and surroundings. Interesting features emerge comparing the distribution of diversity in and around Paris and London. While in Paris diversity is more concentrated in the banlieu (Seine-Saint-Denis being more diverse than Paris), the opposite is true for London where diversity is more concentrated in the core (Inner London being more diverse than Outer London). Vienna appears in the top ten only in 2001, following the immigrant inflows from Eastern Europe after 1989. Rural regions are at the bottom of the ranking both in 1991 and 2001. In 1991, the group of regions at the bottom end shows nearly no diversity and includes only rural Italian and Spanish regions. The picture is different in 2001. Some degree of diversity also 
characterises the most homogenous regions and some of the Italian and Spanish regions have been replaced by rural regions in France and Belgium in terms of lack of diversity.

Table 2: Most and least diverse European regions, 1991 and 2001

\begin{tabular}{|c|c|c|c|c|c|}
\hline \multirow[t]{3}{*}{ Most diverse } & \multicolumn{2}{|c|}{1991} & & \multicolumn{2}{|c|}{2001} \\
\hline & \multicolumn{3}{|c|}{ Share of } & \multicolumn{2}{|r|}{ Share of } \\
\hline & Simpson & foreigners & & Simpson & foreigners \\
\hline Inner London (UK) & 0.334 & $27.8 \%$ & Inner London (UK) & 0.409 & $33.6 \%$ \\
\hline Seine-Saint-Denis (FR) & 0.261 & $24.1 \%$ & Seine-Saint-Denis (FR) & 0.315 & $27.9 \%$ \\
\hline Outer London (UK) & 0.230 & $18.0 \%$ & Outer London (UK) & 0.304 & $22.9 \%$ \\
\hline Paris (FR) & 0.228 & $21.7 \%$ & Paris (FR) & 0.243 & $21.9 \%$ \\
\hline Bruxelles (BE) & 0.223 & $28.6 \%$ & Hauts-de-Seine (FR) & 0.208 & $18.1 \%$ \\
\hline Hauts-de-Seine (FR) & 0.190 & $17.4 \%$ & Val-de-Marne (FR) & 0.203 & $19.4 \%$ \\
\hline Val-de-Marne (FR) & 0.166 & $17.6 \%$ & Val-d'Oise (FR) & 0.191 & $17.8 \%$ \\
\hline Val-d'Oise (FR) & 0.162 & $15.7 \%$ & Bruxelles (BE) & 0.182 & $27.1 \%$ \\
\hline Rhône (FR) & 0.136 & $13.8 \%$ & Wien (AT) & 0.181 & $16.4 \%$ \\
\hline Leicestershire (UK) & 0.136 & $9.1 \%$ & Berkshire (UK) & 0.175 & $13.1 \%$ \\
\hline \multirow[t]{3}{*}{ Least diverse } & \multicolumn{2}{|c|}{1991} & & \multicolumn{2}{|c|}{2001} \\
\hline & \multicolumn{3}{|c|}{ Share of } & \multicolumn{2}{|r|}{ Share of } \\
\hline & Simpson & \multicolumn{2}{|l|}{ foreigners } & Simpson & foreigners \\
\hline Taranto (IT) & 0.001 & $0.1 \%$ & Benevento (IT) & 0.005 & $0.4 \%$ \\
\hline Terni (IT) & 0.001 & $0.1 \%$ & Vandée (FR) & 0.005 & $0.4 \%$ \\
\hline Albacete (ES) & 0.001 & $0.1 \%$ & Taranto (IT) & 0.004 & $0.6 \%$ \\
\hline Badajoz (ES) & 0.001 & $0.1 \%$ & Oristano (IT) & 0.004 & $0.3 \%$ \\
\hline Jaen (ES) & 0.001 & $0.1 \%$ & Ypres (BE) & 0.004 & $0.3 \%$ \\
\hline Ciudad Real (ES) & 0.001 & $0.1 \%$ & Enna (IT) & 0.004 & $0.4 \%$ \\
\hline Zamora (ES) & 0.001 & $0.1 \%$ & Tâmega (PT) & 0.004 & $0.5 \%$ \\
\hline Isernia (IT) & 0.001 & $0.1 \%$ & Brindisi (IT) & 0.004 & $0.4 \%$ \\
\hline Campobasso (IT) & 0.001 & $0.1 \%$ & Eeklo (BE) & 0.004 & $0.2 \%$ \\
\hline Chieti (IT) & 0.000 & $0.0 \%$ & Dixmude (BE) & 0.002 & $0.6 \%$ \\
\hline Source: & \multicolumn{5}{|c|}{$\begin{array}{l}\text { Data are for } 1991 \text { and } 2001 \text { except for the Netherlands (1990 and 2000) and France (1991 } \\
\text { and 1999). }\end{array}$} \\
\hline Notes: & \multicolumn{5}{|c|}{ Finnish and some German regions are excluded (1991 data are not available). } \\
\hline
\end{tabular}


It is common sense to believe that US cities are very diverse 'melting pots', while European cities are generally considered more homogenous both within (low $\alpha$ diversity, in the classification of Whittaker 1972) and between themselves (low $\beta$ diversity, following the same classification). Although a direct comparison is not possible, useful indications concerning the validity of this statement can be drawn by comparing Table 1 with the data presented by Ottaviano and Peri (2005, Table 2) for US cities. ${ }^{6}$ A more complex picture seems to appear. The most diverse US cities are Los Angeles and New York with a share of foreign born in total population of respectively $37 \%$ and $31 \%$ in 1990 (corresponding to diversity indexes in the range of 0.5 to 0.6 ). The percentage is not dramatically different from the percentage of foreign population in the most diverse European regions in 2001 (Inner London reached 33\% in 2001). Differences are apparently larger at the bottom. The least diverse European regions have a share of foreigners in total population that is smaller than $0.5 \%$ whereas their counterparts in the US (such as Cincinnati and Pittsburgh) reach a share of $2.3 \%$. Nevertheless, European regions have levels of $\alpha$-diversity that are comparable with those of US cities and span a range of diversity ( $\beta$-diversity) that is not significantly smaller than the range of diversity spanned by US cities.

\section{Theoretical model}

To structure the empirical analysis, we use the theoretical framework developed by Ottaviano and Peri (2006), who model an open system of cities in which 'diversity' affects both the productivity of firms and the satisfaction of consumers through localised external effects. Both the model and the identification procedure of the impact of diversity on city dwellers build on Roback (1982).

The framework considers a system of a large number $N$ of regions, indexed by $c=1, \ldots, N$. There are two factors of production, labour (perfectly mobile) and land

\footnotetext{
${ }^{6}$ Ottaviano and Peri (2006) use 'country of birth' as identity marker. Data are therefore directly comparable with our data for the UK and Ireland but not for the rest of the regions (for which we use 'citizenship'). The higher values of the Simpson index for US cities also depends on the larger number of 'cultural' groups used by Ottaviano and Peri (as the Simpson index varies with both the number and relative size of groups).
} 
(fixed). The total amount of land is exogenously allocated to regions and $H_{c}$ denotes the amount land in region $c$. To ensure that the rental income of workers, if any, is independent of residence and therefore does not affect migration choices, land is assumed to be owned by locally resident landlords.

Total supply of labour is $L$ and each worker inelastically supplies one unit of work. $L_{c}$ denotes the number of workers living and working in region $c$. In order to rule out commuting, intraregional commuting costs are zero and interregional commuting costs are prohibitive, so we can focus on the interregional allocation of workers.

Workers are identical in terms of attributes that are relevant for market interactions, but they differ in terms of non-market attributes, which exogenously classifies them into $M$ different groups ('cultural identities') indexed by $i=1, \ldots, M$. The diversity of regional population is measured by $d_{c}$ (calculated as in (1)). Diversity affects both production and consumption as an externality that can be either positive or negative. The objective is to identify the dominant externality (consumption or production) and its sign.

As a result of those assumptions, the interregional allocation of land is exogenously given while the interregional allocation of labour will be endogenously determined in equilibrium. Similarly, the degree of cultural diversity for the system is exogenously given, while intraregional diversity is endogenously determined by the entry decisions of firms and the migration decision of workers.

Preferences are defined over the consumption of land $H$ and a homogenous good $Y$ that is freely traded among regions. The utility of a typical worker of group $i$ in region $c$ is given by:

(2) $U_{i c}=A_{U}\left(d_{c}\right) H_{i c}^{1-\mu} Y_{i c}^{\mu}$, where $0<\mu<1$.

In (2), $H_{i c}$ and $Y_{i c}$ are land and good consumption, while $A_{U}\left(d_{c}\right)$ captures the consumption externality associated with local diversity $d_{c}$. If the first derivative $A_{U}$ ' $\left(d_{c}\right)$ is positive, then diversity has a positive effect on workers utility (i.e., an amenity effect). If the first derivative $A_{U}$ ' $\left(d_{c}\right)$ is negative, then diversity has a negative affect on workers utility (i.e., a disamenity effect). Workers move to the region that offers them 
the highest utility. Given (2) and utility maximisation, the indirect utility function is given by:

$$
V_{i c}=(1-\mu)^{1-\mu} \mu^{\mu} A_{U}\left(d_{c}\right) \frac{E_{i c}}{r_{c}^{1-\mu} p_{c}^{\mu}}
$$

where $E_{i c}$ is workers expenditures. Given our assumption about land ownership, $E_{i c}$ will consist of wage only: $E_{i c}=w_{c}$.

As to production, good $\mathrm{Y}$ is supplied by perfectly competitive firms using both land and labour as input. The typical firm in a region $c$ produces according to the following technology:

(4) $Y_{j c}=A_{Y}\left(d_{c}\right) H_{j c}^{1-\alpha} L_{j c}^{\alpha}$, where $0<\alpha<1$.

In (4), $H_{i c}$ and $L_{i c}$ are land and labour inputs, while $A_{Y}\left(d_{c}\right)$ captures the productivity externality associated with local diversity $d_{c}$. If the first derivative $A_{Y}$ ' $\left(d_{c}\right)$ is positive, then diversity has a positive effect on firms' productivity (i.e., a positive productivity effect). If the first derivative $A_{Y}{ }^{\prime}\left(d_{c}\right)$ is negative, then diversity has a negative affect on firms productivity (i.e., a negative productivity effect). Given (4) and profit maximisation, it is possible to solve for the marginal cost pricing condition:

$$
p_{c}=\frac{r_{c}^{1-\alpha} w_{c}^{\alpha}}{(1-\alpha)^{1-\alpha} \alpha^{\alpha} A_{Y}\left(d_{c}\right)}
$$

As $Y$ is freely traded, its price will be the same everywhere and we can choose it as numeraire, i.e. $p_{c}=1 .^{7}$

\footnotetext{
${ }^{7}$ With reference to the empirical analysis, it is important to note that by imposing $p_{c}=1$, we are de facto requiring that the law-ofone-price holds for tradable goods and that land rents are a reasonable approximation of non-tradable goods prices (in the model, as land is the only fixed factor, differences in local prices are entirely driven by land rents).
} 
We can now determine the spatial equilibrium. This is identified by a set of prices for labour and land $\left(w_{c}, r_{c}\right)$ with $c=1, \ldots, N$ such that in all regions workers and landlords maximise their utilities given their budget constraints, firms maximise profits given their technological constraints, factor and product markets clear. At the equilibrium, no worker has an incentive to move. For an interior equilibrium to exist (i.e., $L_{c}>0$ for any $c=1, \ldots, N)$, workers must be indifferent between locations, i.e. their indirect utility is equalised across regions:

$$
V_{i c}=V_{i k} \forall k, c=0 \ldots N
$$

In what follows, we will refer to (6) as the 'free migration condition'. Similarly, in equilibrium no firm has an incentive to exit or enter the market. This is ensured by the marginal cost pricing condition that, given the choice of numeraire, can be re-written as:

$$
r_{c}^{1-\alpha} w_{c}^{\alpha}=(1-\alpha)^{1-\alpha} \alpha^{\alpha} A_{Y}\left(d_{c}\right)
$$

In what follows, we will refer to (7) as the 'free entry condition'. ${ }^{8}$ In order to use the model for the empirical investigation, it is necessary to solve for the rent and wage levels at the equilibrium allocation. This requires solving together the free migration condition (6) and the free entry condition (7) while taking account of (3). The result is the 'wage equation':

$$
\ln w_{c}=\frac{(1-\mu) \eta_{Y}-(1-\alpha) \eta_{U}}{1-\alpha \mu}+\frac{1}{1-\alpha \mu} \ln \left(\frac{\left[A_{Y}\left(d_{c}\right)\right]^{1-\mu}}{\left[A_{U}\left(d_{c}\right)\right]^{1-\alpha}}\right)
$$

and the 'rent equation':

(9) $\quad \ln r_{c}=\frac{\eta_{Y}+\alpha \eta_{U}}{1-\alpha}+\frac{1}{1-\alpha \mu} \ln \left(A_{Y}\left(d_{c}\right)\left[A_{U}\left(d_{c}\right)\right]^{\alpha}\right)$

where $\eta_{Y}=(1-\alpha)^{1-\alpha} \alpha^{\alpha}, \eta_{Y} \equiv(1-\mu)^{1-\mu} \mu^{\mu} / v$ and $v$ is the value of the indirect utility function at the equilibrium (the same across all regions).

\footnotetext{
${ }^{8}$ The free migration and the free entry conditions can then be solved to determine the spatial allocation of workers. A complete discussion is given in Ottaviano and Peri (2006).
} 
Equations (8) and (9) give the relation between diversity and factors prices and represent the theoretical foundation of our empirical investigation. In the wake of Roback (1982), they must be estimated together as the estimation of only one of them would run into an identification problem. To see this, consider estimating equation (9). A positive correlation between diversity and wages would be consistent with both a disamenity effect $\left(A_{U}^{\prime}\left(d_{c}\right)<0\right)$ and a positive productivity effect $\left(A_{Y}{ }^{\prime}\left(d_{c}\right)>0\right)$. Analogously, a positive correlation between diversity and rents would be consistent with both an amenity effect $\left(A_{U}{ }^{\prime}\left(d_{c}\right)>0\right)$ and a positive productivity effect $\left(A_{Y}{ }^{\prime}\left(d_{c}\right)>0\right)$. Only the joint estimation of (8) and (9) will allow the identification of the dominant effect. Specifically:

$$
\begin{array}{lclll}
\frac{\partial r_{c}}{\partial d_{c}}>0 & \text { and } & \frac{\partial w_{c}}{\partial d_{c}}>0 & \text { iff dominant positive productivity effect } & A_{Y}{ }^{\prime}\left(d_{c}\right)>0 \\
\frac{\partial r_{c}}{\partial d_{c}}>0 & \text { and } & \frac{\partial w_{c}}{\partial d_{c}}<0 & \text { iff dominant consumption amenity } & A_{U}{ }^{\prime}\left(d_{c}\right)>0 \\
\frac{\partial r_{c}}{\partial d_{c}}<0 & \text { and } & \frac{\partial w_{c}}{\partial d_{c}}<0 & \text { iff dominant negative productivity effect } & A_{Y}{ }^{\prime}\left(d_{c}\right)<0 \\
\frac{\partial r_{c}}{\partial d_{c}}<0 & \text { and } & \frac{\partial w_{c}}{\partial d_{c}}>0 & \text { iff dominant consumption disamenity } & A_{Y}{ }^{\prime}\left(d_{c}\right)<0
\end{array}
$$

Figure 5 provides a graphical representation of the spatial equilibrium and the associated identification problem. Regional nominal wages $(w)$ are measured along the vertical axis and regional land rents $(r)$ along the horizontal one. Downward sloping lines depict the 'free entry condition', i.e. the combination of rents and wages that make firms indifferent across locations. Their downward slope reflects the fact that firms can earn the same profit in different regions provided that higher wages correspond to lower rents and vice-versa. Upward sloping lines depict the 'free migration condition', i.e. the combination of rents and wages that make workers indifferent across locations. Their upward slope reflects the fact that workers can achieve the same utility ('real wage') in 
different regions provided that higher rents correspond to higher wages and vice-versa. The intersection between the two curves gives the wage and rent equilibrium.

Local diversity $d_{c}$ acts as a shift parameter on the two curves. A positive shock to diversity shifts the free entry condition upward (downward) if diversity has a positive (negative) productivity effect. It shifts the free migration condition downward (upward) if diversity has a consumption amenity (disamenity) effect. We can therefore identify the dominant effect of diversity by looking at the impacts of shocks on the equilibrium factor prices.

Suppose A represents the initial equilibrium at factor prices $(r, w)$. Suppose also that there is a shock to diversity and we observe higher wages $\left(w^{\prime}>w\right)$ after the shock.

Figure 5 shows that in principle this could be associate either with a upward shift of the free entry condition (point B) indicating a positive productivity effect; or with an upward shift of the free migration condition (point $\mathrm{C}$ ) indicating a negative effect on workers quality of life (or consumption disamenity). To distinguish whether higher wages signal higher productivity or worse quality of life, additional information is needed. In Figure 5 that is provided by rents: whereas higher productivity is associated with higher wages and higher land rents (point B), worse quality of life is associated with higher wages but lower land rents (point C). By symmetry the foregoing arguments can be applied to downward shifts of the firm and worker indifference lines. A reduction in productivity shifts the firm line downward, which reduces both wages and land rents (point D). An improvement in the quality of life shifts the worker line downward, thus decreasing wages and increasing land rents (point E). 
Figure 5: The spatial equilibrium

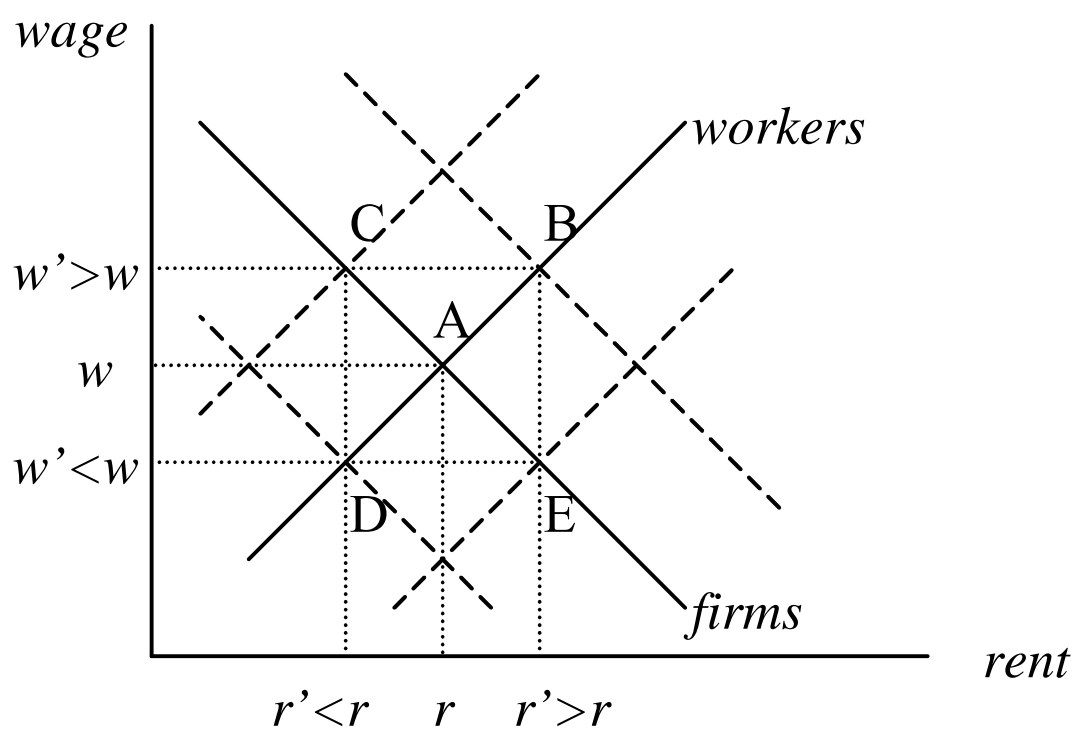

Table 3 summarizes the overall identification procedure that will be used in Section 7 to assess whether and to what extent diversity affects productivity across EU regions.

Table 3: Identification strategy

\begin{tabular}{|l|l|l|l|}
\hline \multicolumn{2}{|c|}{} & \multicolumn{2}{|l|}{ Rent variation } \\
\cline { 3 - 4 } & Positive & Negative \\
\hline $\begin{array}{l}\text { Wage } \\
\text { variation }\end{array}$ & Positive & $\begin{array}{l}\text { Positive productivity } \\
\text { effect }\end{array}$ & Disamenity effect \\
\cline { 2 - 4 } & Negative & Amenity effect & $\begin{array}{l}\text { Negative productivity } \\
\text { effect }\end{array}$ \\
\hline
\end{tabular}

Before moving to the empirical results, it is however important to discuss the consequences of Europe's low labour mobility for the empirical implementation. Consider the extreme case of no labour mobility. In such case, the 'free migration condition' becomes vertical and wage differentials measure productivity differentials. If 
this were the case for Europe, we could simply estimate the wage equation and identify wage responses to diversity shocks as productivity effects. Since labour mobility in Europe is low but it is not absent (particularly among migrants), we will nevertheless estimate the rent regressions in order to rule out any possibility that higher wages reflect the disamenity effects of diversity.

\section{Econometric results}

Before turning to the empirical investigation, it is important to highlight the additional limitations we face when working with European data with respect to US-based studies tackling our same issues.

Most of the studies surveyed in Section 2 (Borjas 1994, 1999 and 2003, Card 2001, Ottaviano and Peri 2005 and 2006 among others) construct city-specific economic indicators (such as wages of skilled/unskilled native/foreign born) directly from microlevel dataset, usually the PUMS dataset. With this fine level of disaggregation individuals sharing similar characteristics (education level, work experience, ethnicity, age, etc.) are merged together in internally homogeneous cells and then well defined relations are investigated. For example, a standard question in this literature is whether the inflow of migrants has an impact on white native's hourly wages. This kind of investigation can be performed for different level of education, tenure and ethnicity. Our European study relies instead on meso-level data, meaning that we have information on regional averages instead of having aggregates built from individual data. This limitation makes it impossible to discriminate, for example, between natives' and foreigners' wages. At the same time we cannot identify whether natives and foreigners are high or low skilled: we only know, for example, the share of workers having tertiary education, irrespectively of the regional distribution of natives and foreigners.

We now present the results of the empirical analysis, which is carried out in four steps. First, following the identification strategy set out in Section 6, we estimate the wage equations. As wage data for European regions and cities are scattered and not available 
at NUT 3 level, we use GDP per capita as a proxy. ${ }^{9}$ Under the model assumption of free firm mobility the two measures are equivalent, as profits are equalised across regions and income differentials are entirely driven by wage differentials.

Second, we estimate the rent equations. EU-wide comparable data for land rents at city level are not available and data for a close proxy such as house prices are only available for a restricted number of major cities. However, in our theoretical model, rents de facto capture non-tradable good prices, which we proxy by the average prices (in logs) of two-forchettes restaurants as detailed in Section $3 .^{10}$

Third, since our independent variable 'diversity' is potentially endogenous, we perform instrumental variables (IV) estimations in order to net out the (possibly positive) effect running from wages to diversity and the (possibly negative) effect running from rents to diversity.

\section{First step: Income regressions}

The income equation we estimate is the following:

$$
\ln y_{c}=D_{r}+\beta \operatorname{div}_{c}+\boldsymbol{\varphi}^{I} \boldsymbol{X}_{c}+e_{c}
$$

where $c$ indexes the NUTS3 provinces. Once we exclude formerly Eastern Germany provinces, we have 844 NUTS 3 observations and a number of NUTS 2 regions equal to 171 so that the average number of provinces included in a region is around five. As already discussed, the dependent variable $\left(\ln y_{c}\right)$ is GDP per capita (in logs). The key regressor is the province's diversity $\left(\operatorname{div}_{c}\right)$. We use two measures of diversity: the Simpson index (see Section 4) and the simple share of foreigners in total population. In some specifications, this will be accompanied by the Simpson index calculated only among foreigners as in Ottaviano and Peri (2006). ${ }^{11}$ We include a set $\boldsymbol{X}_{\boldsymbol{c}}$ of standard control variables such as the share of agriculture in total employment $\left(a g r i_{c}\right)$ to control for differences in industrial structure and the share of inhabitants with at least secondary

\footnotetext{
${ }^{9}$ REGIO also contains data for 'Compensation of employees' but scattered and only available at NUTS 2 level.

${ }^{10}$ Where data availability makes computation possible, the correlation between restaurant prices and house prices is typically large and positive. For example, in a sample of 12 major Italian cities such correlation was roughly 70 per cent in 2001 .

${ }^{11}$ As from Section 3 population is classified by citizenship in all countries apart from the UK and Ireland for which we use the 'country of birth' .
} 
education $\left(e d u_{c}\right)$ to control for differences in human capital endowments. ${ }^{12}$ The density of population $\left(\right.$ dens $\left._{c}\right)$ is introduced to control for those 'non-pecuniary' externalities that derive from sheer proximity of economic actors. ${ }^{13}$ Market potential $\left(\operatorname{mpot}_{c}\right)$ controls for the 'pecuniary' externalities that derive from the agglomeration of economic activities, as highlighted by the 'new economic geography' literature (see Redding and Venables 2004; Ottaviano and Pinelli 2006). In all regressions, we introduce NUTS 2 region fixed effects, $D_{r}$. Region fixed effects $\left(D_{r}=1\right.$ for the all the NUTS3 regions belonging to a specific NUTS 2 region; 0 otherwise) control for those characteristics, such as institutions and other NUTS2-specific variables that apply to all the provinces (NUTS3). When NUTS2 fixed effects are introduced, only the provincial deviations from the NUTS2 baseline is left to be explained.

Table 4 shows the results of the basic income regressions, estimated with OLS. Robust standard errors are also reported in brackets as heteroskedasticity often characterises cross-regional analyses. Columns (1) and (2) report the results of specifications where the only regressors are the overall Simpson index and the share of foreigners plus the Simpson index calculated among foreigners only. The diversity indices are positive and strongly significant, suggesting positive correlations with the log of GDP per capita, which is our wage proxy. NUTS2 dummies already explain a lot of variation: regressions including NUTS2 dummies alone show R-squared around 0.69. Nonetheless, the inclusion of diversity indices significantly adds explanatory power. In columns (3) and (4) we replicate the two previous estimations adding some of the controls described above. The coefficients of diversity indices are a bit smaller but still strongly significant. The coefficients of controls show expected signs, except the one of market potential that is, however, not significant. The share of agriculture has a negative coefficient, which is significant in column (3), consistently with most findings in literature (see, for example, Bivand and Brundstad 2003). The human capital variable has a positive and strongly significant coefficient, consistent with the growth literature

\footnotetext{
${ }^{12}$ Ssee Temple (1999) for a review of the recent literature on income and growth regressions.

${ }^{13}$ Local external effects can be positive, due to easier non-market interactions leading to technological externalities (see Ciccone 2002; Ciccone and Hall 1996) or negative, due to higher congestion and consequent waste of resources that make interactions difficult.
} 
(Temple 2001). Finally, the density of population has a positive coefficient hinting at positive agglomeration effects as in Ciccone and Hall (1996) and Ciccone (2002).

Table 4: wage regressions - OLS

\begin{tabular}{|c|c|c|c|c|}
\hline Dep.Variable: $\log ($ GPDpc $)$ & (1) & (2) & (3) & (4) \\
\hline \multirow{2}{*}{ Simpson Index } & $5.73068 * * *$ & & $3.66791 * * *$ & \\
\hline & {$[1.60738]$} & & {$[0.76727]$} & \\
\hline \multirow{2}{*}{ Share of Foreigners } & & $4.82905 * * *$ & & $3.21975 * * *$ \\
\hline & & {$[0.82310]$} & & {$[0.50362]$} \\
\hline \multirow{2}{*}{ Simpson Index Among Foreigners } & & $0.94970 * * *$ & & $0.34025 * *$ \\
\hline & & {$[0.14410]$} & & {$[0.16062]$} \\
\hline \multirow{2}{*}{ Share of Agriculture } & & & $-0.00816^{* *}$ & -0.00648 \\
\hline & & & {$[0.00364]$} & {$[0.00414]$} \\
\hline \multirow{2}{*}{ Human Capital } & & & $0.02387 * * *$ & $0.02138 * * *$ \\
\hline & & & {$[0.00436]$} & {$[0.00490]$} \\
\hline \multirow{2}{*}{ Density } & & & $0.00001 *$ & $0.00002 * * *$ \\
\hline & & & {$[0.00001]$} & {$[0.00001]$} \\
\hline \multirow{2}{*}{ Market Potential } & & & -0.00001 & -0.00001 \\
\hline & & & {$[0.00001]$} & {$[0.00001]$} \\
\hline NUTS 2 Dummies & yes & yes & yes & yes \\
\hline Observations & 787 & 787 & 679 & 679 \\
\hline R-squared & 0.80 & 0.82 & 0.88 & 0.89 \\
\hline \multicolumn{5}{|c|}{ Robust standard errors in brackets. Observations are weighted for working population. } \\
\hline \multicolumn{5}{|c|}{$*$ significant at $10 \% ; * *$ significant at $5 \% ; * * *$ significant at $1 \%$} \\
\hline
\end{tabular}

Under the realistic assumption of limited labour mobility, in the light of Figure 5 such results would point at a positive effect of diversity on firms' productivity. Nevertheless, in the presence of labor mobility, higher wages in more diverse regions could simply reflect aversion to diversity rather than a genuine effect on productivity. To rule out this possibility, we now study the relationship between diversity and local prices.

Second step: Price regressions

The price equation we estimate is the following: 


$$
\ln p_{c}=D_{r}+\gamma d i v_{c}+\varphi^{P} \boldsymbol{X}_{c}+e_{c}
$$

The dependent variable $\left(\ln p_{c}\right)$ is the log of average restaurant price in the NUTS3 region. As before, the key regressor is regional diversity (div $v_{c}$.). Standard control variables are included together with NUTS2 region fixed effects, as in the income regression.

Table 5 shows the results of the prices regressions following the same structure of Table 4. All regression have large explanatory power once we control for NUTS2 fixed effects. This implies that most of the variation in restaurant prices is not explained by local NUTS3 characteristics but possibly by less 'local' determinants. However, coefficients are positive and significant for all the diversity measures, thus revealing a (small) positive relation between diversity and land rents. This small effect is consistent with low labour mobility and thus a vertical free migration condition. The coefficients of control variables are never significantly different from zero. The exception is the coefficient on the share of agriculture. This is negative and marginally significant in specifications (3) and (4), confirming that a higher specialisation in agriculture is negatively associated with productivity.

Following our identification strategy, the positive signs of the diversity measures' coefficients rule out the possibility that diversity acts as a consumption disamenity and, thus, point out a positive correlation between diversity and productivity. 
Table 5: Restaurant prices regressions - OLS

\begin{tabular}{|c|c|c|c|c|}
\hline Dep.Variable: $\log ($ RestPrice $)$ & (1) & (2) & (3) & (4) \\
\hline \multirow{2}{*}{ Simpson Index } & $1.64327 * * *$ & & $1.80630 * * *$ & \\
\hline & {$[0.33582]$} & & {$[0.48860]$} & \\
\hline \multirow{2}{*}{ Share of Foreigners } & & $1.14742 * * *$ & & $0.90911 * * *$ \\
\hline & & {$[0.27731]$} & & {$[0.31238]$} \\
\hline \multirow{2}{*}{ Simpson Index Among Foreigners } & & $0.24145 * * *$ & & $0.18509 * *$ \\
\hline & & {$[0.08272]$} & & {$[0.08788]$} \\
\hline \multirow{2}{*}{ Share of Agriculture } & & & -0.00486 & $-0.00510^{*}$ \\
\hline & & & {$[0.00299]$} & {$[0.00294]$} \\
\hline \multirow{2}{*}{ Density } & & & 0 & 0.00001 \\
\hline & & & {$[0.00001]$} & {$[0.00001]$} \\
\hline \multirow{2}{*}{ Market Potential } & & & -0.00001 & 0 \\
\hline & & & {$[0.00001]$} & {$[0.00001]$} \\
\hline NUTS 2 Dummies & yes & yes & yes & yes \\
\hline Observations & 686 & 686 & 630 & 630 \\
\hline R-squared & 0.96 & 0.96 & 0.97 & 0.97 \\
\hline \multicolumn{5}{|c|}{ Robust standard errors in brackets. Observations are weighted for working population. } \\
\hline \multicolumn{5}{|c|}{$*$ significant at $10 \% ; * *$ significant at $5 \% ; * * *$ significant at $1 \%$} \\
\hline
\end{tabular}

Third step: Instrumental variables

Short of a randomized experiment, we cannot be sure that the positive correlation found between diversity and productivity reveals a causal link from the former to the latter due to possible reverse causation. We address this concern through instrumental variables (IV). The idea is to substitute our potentially endogenous diversity measures by a set of proxies correlated with the change in the diversity of regions from 1991 to 2001 but not otherwise correlated with the residuals of regressions (11) and (12). The related literature has proposed two approaches to construct such instruments. The first build on the idea that migrants enter through 'gateways' and tend to settle in their proximity due 
to the presence of costs of travelling and spreading information as well as the existence of ethnic networks (Ottaviano and Peri 2006). In this case, the distance from such 'gateways' is presumably highly correlated with diversity and exogenous to local income, prices and productivity. The second approach is the 'shift-share methodology' firstly applied by Card (2001) and, more recently, by Saiz (2003) and Ottaviano and Peri (2006). In the latter methodology, which we follow in this section, the key idea is that migrants tend to settle close to where migrants of the same provenience already reside. Accordingly, the predicted end-of-period composition of a region's population in 2000 can be computed on the basis of its beginning-of-period composition in 1990 by attributing to each group in the region its average growth rate in the country to which the region belongs to from 1990 to 2000. Alternatively, one could use the average growth rate in the EU as a whole. We prefer the national growth rate as there are differential behaviours of different ethnic groups that are country-specific. These differential behaviours arise from the heterogeneous nature of European countries' populations: different languages, different colonial history of sending countries and different cultures. In Figures 6 and 7 (where "Rest" indicates foreigners from Oceania and unknown origin) we report the composition of foreign population for years 1990 and 2000 respectively. It is easy to spot patterns that are more likely to be countryspecific than widespread across European countries. 
Figure 6: Composition of foreign population in 1990

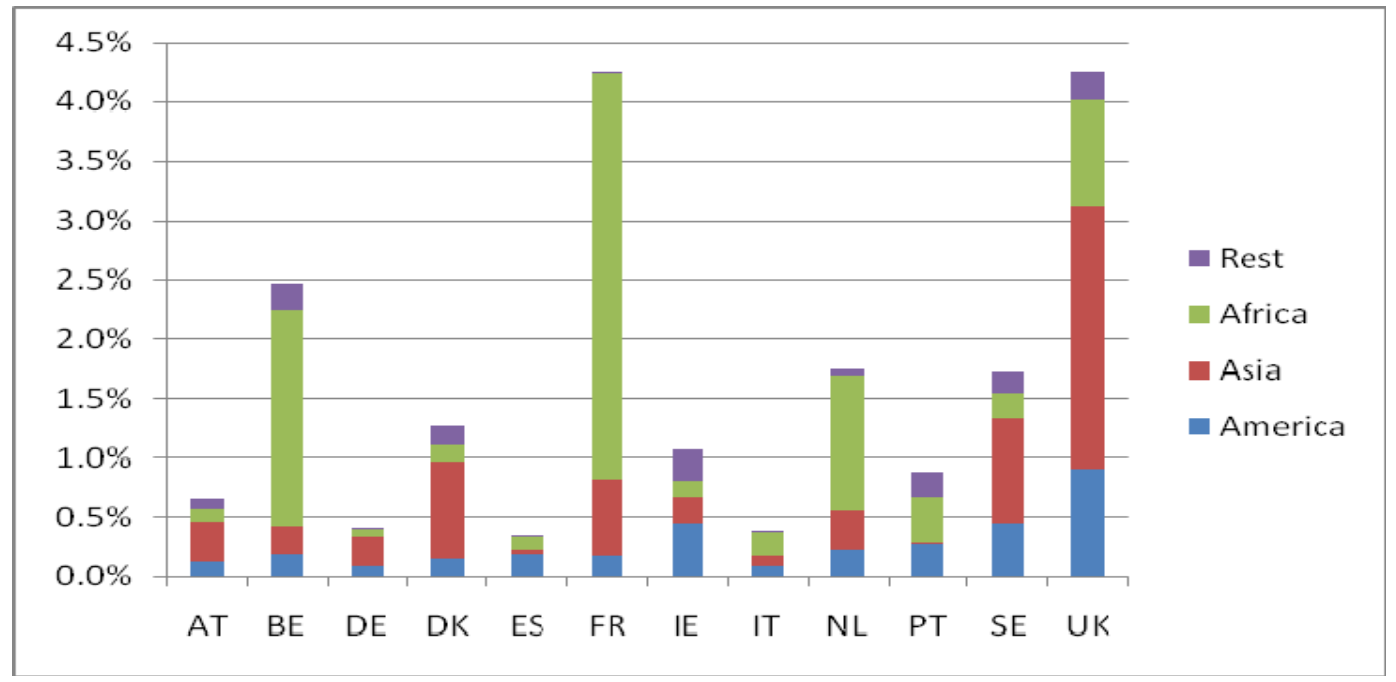

Figure 7: Composition of foreign population in 2000

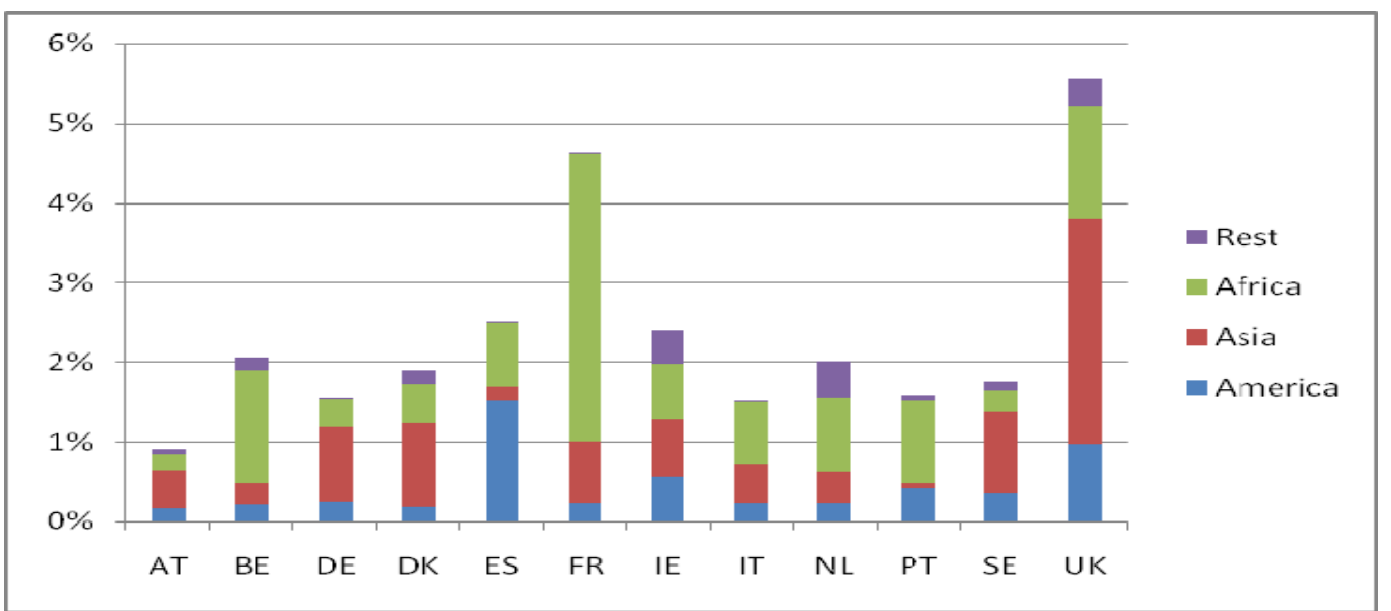

The procedure we use to build our instruments relies on the assumption that in 1990 the distribution of foreigners in the different NUT3 regions of a country were only driven by non-economic drivers of location choices of the immigrants, such as the existence of previously formed enclaves. We are confident that, at least for countries in which migrants began to settle in late years, this can hold. Examples of this kind of countries 
are Austria, Germany, Ireland, Italy, Portugal and Spain that in 1990 hosted around or less than $1 \%$ of immigrants.

To construct the predicted shares of foreigners, we start with building a nation-wide growth rate $g_{n f}$ for each ethnic group $f$ (Europe, America, Asia, Africa and Rest of the World) in each country $n$. Formally:

$g_{n f}=\left(N_{n f 2000}-N_{n f 1990}\right) / N_{n f 1990}$

where $N_{\text {nf1990 }}$ and $N_{\text {nf2000 }}$ are the number of inhabitants of ethnic group $f$ in country $n$ in years 1990 and 2000 respectively. Then, for each NUTS3 region $c$ belonging to country $n$, we construct the predicted number of inhabitants in year 2000 as:

$N^{\prime}{ }_{c 2000}=N_{c f 1990}\left(1+g_{n f}\right)$

Then, for each NUTS3 region, we construct the total predicted population in 2000 , $N^{\prime}{ }_{c 2000}$, by summing the $N^{\prime}{ }_{c f 2000}$ across all ethnic groups $f$. Finally, we follows expression (1) to compute $d^{\prime}{ }_{c}$ as the predicted Simpson Index for each NUTS3 region.

An analogous procedure is applied to compute the predicted share of foreigners in each NUTS3 region, defined as total population minus the autochthonous.

The results of the IV estimations of wages and prices regressions are reported in Table 6. In the wage regressions both the coefficients of the Simpson Index and of the share of foreigners turn out to be smaller than the OLS estimates in Table 5. They are, however, still strongly significant, implying that the positive 'pull effect' of migrants going to places with higher wages has been netted out by the instrument. In fact, the first stage regression shows large F-tests and not negligible R-squared, indicating that instruments are not weak. The coefficients of the Simpson Index among foreigners also remain positive but lose their significancy. Finally, the controls show similar values and are always significant as in Table 5, with the exception of market potential. 
Table 6: Instrumental variable regressions

\begin{tabular}{|c|c|c|c|c|}
\hline \multirow[t]{2}{*}{ Dep.Variable: } & \multicolumn{2}{|c|}{$\log (G P D p c)$} & \multicolumn{2}{|c|}{$\log ($ RestPrice) } \\
\hline & \multicolumn{4}{|c|}{ Second Stage } \\
\hline \multirow{2}{*}{ Simpson Index } & $2.44676 * * *$ & & $2.24448 * * *$ & \\
\hline & {$[0.70145]$} & & {$[0.72176]$} & \\
\hline \multirow{2}{*}{ Share of Foreigners } & & $2.30350 * * *$ & & $0.82383 * *$ \\
\hline & & {$[0.50461]$} & & {$[0.41814]$} \\
\hline \multirow{2}{*}{ Simpson Index Among Foreigners } & & 0.1233 & & 0.02727 \\
\hline & & {$[0.19007]$} & & {$[0.12543]$} \\
\hline \multirow{2}{*}{ Share of Agriculture } & $-0.01017 * * *$ & $-0.00956^{* *}$ & -0.00417 & $-0.00697 * *$ \\
\hline & {$[0.00359]$} & {$[0.00385]$} & {$[0.00307]$} & {$[0.00281]$} \\
\hline \multirow{2}{*}{ Education } & $0.02184 * * *$ & $0.02123 * * *$ & & \\
\hline & {$[0.00381]$} & {$[0.00453]$} & & \\
\hline \multirow{2}{*}{ Density } & $0.00002 * * *$ & $0.00002 * * *$ & 0 & $0.00001 * *$ \\
\hline & {$[0.00001]$} & {$[0.00001]$} & {$[0.00000]$} & {$[0.00000]$} \\
\hline \multirow{2}{*}{ Market Potential } & -0.00001 & -0.00001 & -0.00001 & 0 \\
\hline & {$[0.00001]$} & {$[0.00001]$} & {$[0.00001]$} & {$[0.00001]$} \\
\hline NUTS 2 Dummies & yes & Yes & yes & yes \\
\hline Observations & 555 & 555 & 508 & 508 \\
\hline \multirow[t]{2}{*}{ R-squared } & 0.90 & 0.97 & 0.93 & 0.93 \\
\hline & \multicolumn{4}{|c|}{ First Stage } \\
\hline \multirow{2}{*}{ Predicted Simpson Index } & $0.52830 * * *$ & & $0.52040 * * *$ & \\
\hline & {$[0.09187]$} & & {$[0.09399]$} & \\
\hline \multirow{2}{*}{ Predicted Share of Foreigners } & & $0.61680 * * *$ & & $0.63185 * * *$ \\
\hline & & {$[0.07202]$} & & {$[0.07524]$} \\
\hline \multirow{2}{*}{$\begin{array}{l}\text { Predicted Simpson Index } \\
\text { Among Foreigners }\end{array}$} & & $0.64574 * * *$ & & $0.69154 * * *$ \\
\hline & & {$[0.03884]$} & & {$[0.04032]$} \\
\hline Partial R-squared & 0.43 & $0.67 \mid 0.51$ & 0.41 & $0.70 \mid 0.48$ \\
\hline F-test & 33.07 & $37.9 \mid 173.7$ & 30.65 & $36.4 \mid 166.0$ \\
\hline \multicolumn{5}{|c|}{ Robust standard errors in brackets. Observations are weighted for working population. } \\
\hline
\end{tabular}


In price regressions the previously described 'pull effect' should be negative: we expect that, other things being equal, migrants decide to settle in places where prices are lower. This seems indeed to be the case when we instrument the Simpson Index: its coefficient becomes bigger, meaning that, if any, the effect of the price level on diversity is negative, leading to downward biased estimates in specification (3) of Table 5. Turning to the last specification, the coefficient on the share of foreigners is not significantly different from the OLS regression and the coefficient on the Simpson Index among foreigners is not significant.

Overall, the values and the pattern of significance of the IV results trace the ones of the OLS specifications (3) and (4) in Table 5, pointing at a positive causal relationship from diversity to productivity possibly accompanied by an amenity effect of diversity on consumption.

\section{Conclusions}

Growing evidence on US cities suggests that on average US-born citizens are more productive in a culturally diversified environment. This is robust to instrumental variables techniques, thus implying a causal relationship from diversity to productivity. In the case of Europe, someway similar results have been found for the UK and Germany. The present paper has supplemented these national studies by providing an overview of the relationship between diversity and economic performance across a large set of European regions. This represents a relevant addition to the literature as insights gained from US analyses may not readily apply to the EU given different migration history and different institutional frameworks. .

Based on an original dataset covering the NUT3 regions of 12 countries of the EU15 (Austria, Belgium, Denmark, France, former Western Germany, Ireland, Italy, the Netherlands, Portugal, Spain, Sweden and the United Kingdom), we have found that diversity is positively correlated with productivity and that causation runs from the former to the latter. 


\section{References}

Abadie A. and J. Gardeazabal (2003), The Economic Costs of Conflict: A Case Study for the Basque Country, The American Economic Review, 93 (1), pp. 113-132.

Alesina A., R. Baqir and W. Easterly (1999), Public Goods and Ethnic Division, Quarterly Journal of Economics, 111 (4), pp. 1243-1284.

Alesina A., R. Baqir and C. Hoxby (2004), Political Jurisdictions in Heterogenous Communities, Journal of Political Economy, 112 (2), pp. 384-396.

Alesina A., A. Devleschawuer, W. Easterly, S. Kurlat and R. Wacziarg (2003), Fractionalization, Journal of Economic Growth, 8, pp. 155-194.

Alesina A., E. Glaeser and B. Sacerdote (2001), Why Doesn't the US have a European Style Welfare State?, Brooking Paper on Economic Activity, Fall.

Alesina A., E. La Ferrara (2005), Ethnic Diversity and Economic Performance, Journal of Economic Literature, 43, pp. 762-800.

Angrist J. D., A. D. Kugler (2003), Protective or Counter-Productive? Labour Market Institutions and the Effect of Immigration on EU Natives, Economic Journal, 113, pp. 302-331.

Arcand, J-L., P. Guillaumont and S. Guillaumont Jeanneney (2000), How to Make a Tragedy: on the Alleged Effect of Ethnicity on Growth, Journal of International Development, 12, pp. 925-938.

Bairoch P. (1985), De Jéricho à Mexico: Villes et economie dans l'histoire, Paris, Editions Gallimard.

Berliant M. and M. Fujita (2004), Knowledge Creation as a Square Dance on the Hilbert Cube, Discussion Paper, Kyoto University.

Bivand R. S. and R. J. Brunstad (2004), Regional growth in Western Europe: an Empirical Exploration of Interactions with Agriculture and Agricultural Policy, in European Regional Growth, B. Fingleton (ed.), Springer, New York, pp. 351-375. 
Borjas G.J. (1994), The Economics of Immigration, Journal of Economic Literature, 32, pp. 1667-1717.

Borjas G.J. (1995), The Economic Benefits of Immigration, Journal of Economic Perspectives, 9, pp. 3-22.

Borjas G.J. (1999), Heaven’s Door, Princeton, Princeton University Press.

Borjas, G. (2003) The Labour Demand Curve is Downward Sloping: Reexamining the Impact of Immigration on the Labour Market, Quarterly Journal of Economics, CXVIII (4), pp. 1335-1374.

Borjas G. J., R. Freeman and L. Katz (1997), How Much do Immigration and Trade Affect Labour Market Outcomes?, Brookings Papers on Economic Activity, 1, pp. 1-90.

Butcher K. C. and D. Card (1991), Immigration and Wages: Evidence from the 1980s, American Economic Review, Papers and Proceedings, 81 (2), pp. 292-296.

Card D. (1990), The Impact of the Mariel Boatlift on the Miami Labour Market, Industrial and Labour Relation Review, XLIII, pp. 245-257.

Card D. (2001), Immigrant Inflows, Native Outflows, and the Local labour Market Impacts of Higher Immigration, Journal of Labour Economics, XIX, pp. 22-64.

Ciccone A. (2002), Agglomeration Effects in Europe, European Economic Review, 46, pp. 213-227.

Ciccone A. and R. Hall (1996), Productivity and the Density of Economic Activity, American Economic Review, n. 87, pp. 54-70.

Collier P. (2001), Implication of Ethnic Diversity, Economic Policy, 32, pp. 129-166.

D'Amuri F., G. Ottaviano and G. Peri (2008), The Labor Market Effects of Immigration in Western Germany in the 1990's”, NBER Working Paper No. 13851.

Easterly W. (2001), Can Institutions Resolve Ethnic Conflict?, Economic Development and Cultural Change, Vol. 49, No. 4, pp 687-706. 
Easterly W. and R. Levine (1997), Africa's Growth Tragedy: Policies and Ethnic Division, Quarterly Journal of Economics, 111 (4), pp 1203-1250.

Extra G. and K. Yağmur (eds) (2004), Urban multilingualism in Europe. Immigrant minority languages at home and school, Clevedon, Multilingual Matters.

Fearon J. D. (2003), Ethnic and Culture Diversity by Country, Journal of Economic Growth, 8 (2), pp. 195-222.

Florida R. (2002), The Rise of the Creative Class (tr. it., L'ascesa della nuova classe creativa, Milano, ed. Arnoldo Mondadori Editore SpA).

Friedberg R. (2001), The Impact of Mass Migration on the Israeli Labour Market, Quarterly Journal of Economics, vol. 116(4), pp. 1373-1408.

Gertler M. S., R. Florida, G. Gates, T. Vinodrai (2002), Competiting on Creativity: Placing Ontario's Cities in North American Context, Institute for Competitiveness and Prosperity, Ontario Ministry of Enterprise.

Glaeser E.L., Scheinkman J.A., Shleifer A. (1995), Economic Growth in a CrossSection of Cities, Journal on Monetary Economics, 36(1), pp. 117-144

Head K. and T. Mayer (2004), The Empirics of Agglomeration and Trade, in Henderson $\mathrm{V}$ and J-F Thisse (eds), Handbook of Regional and Urban Economics, vol. 4, Elsevier, Amsterdam.

Jacobs J. (1961), The Death and Life of Great American Cities, New York, Vintage.

Knack S. and P. Keefer (1995), Institutions and Economic Performance: Cross-country Tests using Alternative Institutional Measures, Economics and Politics, 7, pp. 207-227.

La Porta R., F. Lopez de Silanes, Shleifer A. and R. Vishny (1999), The Quality of Government, Journal of Law, Economics and Organisation, 15(1), pp. 222-279.

Lazear E. P. (1999), Globalisation and the Market for Team-Mates, The Economic Journal,109, C15-C40.

Lewis E. (2003), Local Open Economies within the US. How do Industries respond to Immigration?, Federal Reserve Bank of Philadelphia, Working Paper 04. 
Manacorda, M., A. Manning, and J. Wadsworth (2006), The Impact of Immigration on the Structure of Male Wages: Theory and Evidence from Britain, CEP Discussion Paper 754.

O’Reilly C., K. Williams and S. Barsade (1998), Group Democracy and Innovation: Does Diversity Help?, in Research and Managing Groups and Teams, D Gruenfeld et al (eds) JAI Press.

Ottaviano G.I.P. and Peri G. (2005), Cities and Cultures, Journal of Urban Economics, 58, pp. 304-337.

Ottaviano G.I.P. and Peri G. (2006a), The Economic Value of Cultural Diversity: Evidence from US Cities, Journal of Economic Geography, 6, pp. 9-44.

Ottaviano G.I.P. and Peri G. (2006b), Rethinking the Gains of Immigration on Wages, NBER, Working Paper No. 12497.

Ottaviano G.I.P. and Pinelli D. (2006), Market Potential and Productivity: Evidence from Finnish Regions, Regional Science and Urban Economics, 36, pp. 636-657.

Redding S. and A. Venables (2004), Economic Geography and International Inequality, Journal of International Economics 62, pp 53-82.

Roback J. (1982), Wages, Rents and the Quality of Life, Journal of Political Economy, 90, pp. 1275-1278.

Saiz A. (2003) Immigration and Housing Rents in American Cities, Federal Reserve Bank of Philadelphia, Working Paper 03-12.

Sassen S. (1994), Cities in a World Economy, Pine Forge Press, Thousand Oaks, US.

Temple J. (1999), The New Growth Evidence, Journal of Economic Literature, 37, pp. $112-156$

Temple J. (2001), Generalization that aren't, Evidence on Education and Growth, European Economic Review, 45, pp. 905-918.

Whittaker, R.H. (1972), Evolution and Measurement of Species Diversity, Taxon 21 pp 213-251. 
Zimmermann K.F. (2005), European Migration: What do we Know?, Oxford, Oxford University Press. 


\section{HWWI Research Papers}

by the HWWI Research Programme „Migration Research Group“

13. Does citizenship matter? The economic impact of naturalizations in Germany Max Friedrich Steinhardt Hamburg, April 2008

12. The Labor Market Impact of Immigration in Western Germany in the 1990's Francesco D’Amuri, Gianmarco I. P. Ottaviano, Giovanni Peri Hamburg, April 2008

11. Diversity Management and the Business Case Michael Fischer Hamburg, November 2007

10. Labour market entry of migrants in Germany - Does cultural diversity matter?, Anette Haas, Andreas Damelang Hamburg, May 2007

9. Skills and remittances: The case of Afghan, Egyptian, and Serbian immigrants in Germany Florin Vadean Hamburg, April 2007

8. Rethinking the effects of immigration in wages Gianmarco I.P. Ottaviano, Giovanni Peri Hamburg, April 2007

7. Regional disparities in employment of high-skilled foreigners - Determinants and options for migration policy in Germany Carola Burkert, Annekatrin Niebuhr, Rüdiger Wapler Hamburg, March 2007

6. Social relations and remittances: evidence from Canadian micro data Don J. DeVoretz, Florin Vadean Hamburg, February 2007

5. Egyptian, Afghan, and Serbian diaspora communities in Germany: How do they contribute to their country of origin?

T. Baraulina, M. Bommes, T. El-Cherkeh, H. Daume, F. Vadean Hamburg, January 2007

4. Arbeitsmarkt und Migration - eine empirische Analyse der Lohn- und Beschäftigungseffekte der Zuwanderung in Deutschland

Max Steinhardt Hamburg, November 2006

3. Peer Effects, Social Multipliers and Migration at School: An International Comparison Horst Entorf, Martina Lauk Hamburg, July 2006

2. The Impact of Student Diversity in Secondary Schools. An Analysis of the International PISA Data and Implications for the German Education System Katharina Michaelowa, Jean Bourdon Hamburg, July 2006

1. Migration and Innovation. Does Cultural Diversity Matter for Regional R\&D Activity? Annekatrin Niebuhr Hamburg, July 2006 
The Hamburg Institute of International Economics (HWWI) is an independent economic research institute, based on a non-profit public-private partnership, which was founded in 2005. The University of Hamburg and the Hamburg Chamber of Commerce are shareholders in the Institute .

The HWWI's main goals are to:

- Promote economic sciences in research and teaching;

- Conduct high-quality economic research;

- Transfer and disseminate economic knowledge to policy makers, stakeholders and the general public.

The HWWI carries out interdisciplinary research activities in the context of the following research programmes: Economic Trends, Hamburg and Regional Development, World Economy and Migration Research Group. 
Hamburg Institute of International Economics (HWWI)

Heimhuder Str. 71 | 20148 Hamburg | Germany

Phone +49 (0)40 340576 - 0 | Fax +49 (0)40 340576 - 776

info@hwwi.org |www.hwwi.org 